\title{
ANALISIS BIAYA PRODUKSI DENGAN MENGGUNAKAN INFORMASI AKUNTANSI DIFERENSIAL DALAM PENGAMBILAN KEPUTUSAN BETERNAK SENDIRI ATAU MENJALIN PROGRAM KEMITRAAN (STUDI PADA PT. CIOMAS ADISATWA II UNIT KLUNGKUNG)
}

\author{
Ni Luh Ririn Liana D. \\ Jurusan Pendidikan Ekonomi, Fakultas Ekonomi \\ Universitas Pendidikan Ganesha Singaraja, \\ Indonesia \\ e-mail: ririnliana93@gmail.com
}

\begin{abstract}
Abstrak
Penelitian ini bertujuan untuk menentukan besarnya biaya produksi ayam broiler dengan beternak sendiri dan melalui program kemitraan dan menentukan alternatif biaya produksi yang lebih tepat untuk PT. Ciomas Adisatwa II Unit Klungkung. Penelitian ini merupakan penelitian deskriptif kuantitatif. Subjek penelitian ini adalah PT. Ciomas Adisatwa II Unit Klungkung dan objeknya adalah biaya produksi yang digunakan untuk memperoleh bahan baku berupa bibit ayam. Data dikumpulkan dengan metode wawancara dan dokumentasi kemudian dianalisis dengan deskriptif kuantitatif menggunakan analisis biaya diferensial. Hasil penelitian ini menunjukkan bahwa besarnya biaya produksi ayam yang harus dikeluarkan PT Ciomas Adisatwa II Unit Klungkung melalui beternak sendiri yaitu Rp. 3.440.160.000, 00 sedangkan besarnya biaya produksi ayam melaui program kemitraan yaitu Rp. 3.134.880.000, 00, sehingga alternatif beternak ayam melalui program kemitraan menjadi pilihan yang terbaik karena lebih menguntungkan dibandingkan dengan altternatif yang lain.
\end{abstract}

Kata Kunci: biaya produksi, kemitraan

\begin{abstract}
This study aims to determine the cost of production of broiler chickens by raising their own and through partnership programs and determine the alternative cost of production more appropriate for PT. Ciomas Adisatwa II Unit Klungkung. This research is a quantitative descriptive research. The subject of this research is PT. Ciomas Adisatwa II Unit Klungkung and its object is the production cost used to obtain the raw material in the form of chicken seeds. Data were collected by interview and documentation method and then analyzed by quantitative descriptive using differential cost analysis. The results of this study indicate that the cost of chicken production that must be issued PT Ciomas Adisatwa II Unit Klungkung through own breeding is $\mathrm{Rp}$. 3.440.160.000, 00 while the cost of chicken production through partnership program that is $\mathrm{Rp}$. $3.134 .880 .000,00$, so the alternative raising chickens through a partnership program to be the best choice because it is more profitable than the other alternative.
\end{abstract}

Keywords: production cost, partnership

\section{PENDAHULUAN}

Perkembangan bisnis di Indonesia menunjukkan pertumbuhan yang semakin pesat salah satu di antaranya adalah bisnis yang bergerak di bidang makanan. Hal ini dapat dilihat dari semakin banyaknya produk olahan dengan berbagai macam bentuk dan merek dagang yang berbeda, khususnya ayam olahan di pasaran. Beberapa macam diantaranya yaitu chicken nugget dan chicken wings. Selain memiliki 
cita rasa yang disukai oleh masyarakat Indonesia, produk ayam olahan sangat praktis dan mudah untuk didapatkan sehingga permintaan akan produk tersebut terus mengalami peningkatan. Hal ini merupakan salah satu faktor yang mendasari pertumbuhan semakin banyak dan semakin berkembang perusahaan ayam olahan.

Pertumbuhan bisnis ini menjadikan persaingan antar industri sejenis pun semakin ketat, selain harus berinovasi dalam setiap produk yang diciptakan untuk memenangkan persaingan perusahaan juga harus berupaya mempertimbangkan pengalokasian biaya yang tepat sehingga dapat memberikan keuntungan yang maksimal. Salah satu perusahaan produsen produk olahan daging ayam adalah PT Ciomas Adisatwa, yang merupakan salah satu bagian dari PT. Japfa Tbk.

PT. Ciomas Adisatwa sebagai pemasok bahan baku untuk PT So Good Food, dan juga bekerjasama dengan perusahaan-perusahaan ternama seperti KFC, McDonals dan perusahaan lainnya merupakan perusahaan yang cukup besar. Semakin besar suatu perusahaan, aktivitas di dalam perusahaan tersebut semakin banyak, untuk itu perusahaan harus membuat keputusan-keputusan secara tepat agar berdampak positif bagi perusahaan. Namun pembuatan keputusan yang tepat harus didasari oleh informasiinformasi yang akurat terutama dalam keputusan biaya perolehan bahan baku.

Pengambilan keputusan biaya bahan baku sangat penting di dalam setiap usaha. Karena selain biaya tenaga kerja, biaya bahan baku utama merupakan salah satu faktor yang akan menentukan biaya produksi suatu produk serta biaya overhead lainnya. Pengalokasian biaya harus dilakukan secara benar dan terperinci untuk memudahkan manajemen dalam mengambil keputusan yang tepat. Akuntansi biaya merupakan salah satu bidang akuntansi yang menjelaskan perhitungan biaya yang dikeluarkan dan laba yang akan diperoleh suatu perusahaan. Informasi biaya-biaya yang disajikan dengan rinci dapat digunakan untuk mempermudah manajemen dalam upaya pengambilan keputusan sehingga dapat mencapai laba yang diinginkan oleh perusahaan.

Dalam membuat keputusan, manajemen selalu dihadapkan oleh beberapa alternatif kebijakan yang mungkin akan diambil, untuk mengetahui kebijakan yang lebih tepat manajemen dapat melihatnya melalui biaya diferensial yang timbul di antara beberapa alternatif yang berbeda. Menurut Bustami, dkk. (2009) biaya diferensial adalah selisih biaya atau biaya yang berbeda dalam beberapa alternatif pilihan. Sedangkan menurut Hansen \& Mowen (2009) biaya deferensial merupakan biaya masa depan yang berbeda pada masing-masing alternatif. Semua keputusan berhubungan dengan masa depan, karena itu hanya biaya-biaya masa depan yang dapat menjadi relevan dengan keputusan. Krismiaji (2011) menyatakan bahwa biaya diferensial adalah berbagai perbedaan biaya di antara sejumlah alternatif pilihan yang dapat digunakan perusahaan. Sunarto (2004) menyatakan bahwa biaya diferensial adalah biaya masa yang akan datang yang diperkirakan akan berbeda atau terpengaruh oleh suatu pengambilan keputusan pemilihan diantara berbagai macam alternatif. Biaya tersebut relevan dengan analisis yang dilakukan oleh manajemen untuk pengambilan keputusan. Sedangkan Supomo (2012) menyatakan bahwa biaya diferensial adalah biaya yang berbeda dalam suatu kondisi, dibandingkan dengan kondisi-kondisi yang lain. Kemudian menurut Prawironegoro (2008), biaya diferensial adalah biaya yang berbeda secara keseluruhan diantara alternatifalternatif yang tersedia. Dari definisi-definisi tersebut, dapat disimpulkan bahwa biaya diferensial adalah biaya masa akan datang yang dikeluarkan diantara pilihan alternatif 
p-ISSN : 2599-1418

e-ISSN : 2599-1426
Jurnal Pendidikan Ekonomi Undiksha

Volume 10 No. 1 Tahun 2018 yang ada dan akan disesuaikan dengan kondisi.

Akuntansi diferensial memberikan informasi yang berbeda untuk setiap alternatif, dengan adanya akuntansi diferensial akan memungkinkan manajemen suatu perusahaan memiliki fondasi yang dapat dipertanggungjawabkan dalam suatu pengambilan keputusan. Mulyadi (2001) mengemukakan bahwa informasi akuntansi diferensial merupakan taksiran perbedaan aktiva, pendapatan atau biaya dalam alternatif tindakan tertentu dibandingkan dengan alternatif tindakan lain. Manajer perusahaan harus dapat mempertimbangkan dengan matang biaya perolehan bahan baku suatu produk antara alternatif satu dengan alternatif lainnya untuk mendapatkan keuntungan yang maksimal.

Dalam pengambilan keputusan, manajemen membutuhkan informasi yang relevan dengan keputusan-keputusan yang akan diambil. Informasi akuntansi diferensial menyajikan alternatif tindakan yang akan dilakukan dengan membandingkan biaya dan pendapatan yang relevan untuk beberapa keputusan yang akan diambil. Menurut Halim dan Supomo (2005), informasi akuntansi diferensial menyajikan informasi mengenai taksiran pendapatan, biaya dan atau aktiva yang berbeda jika suatu tindakan tertentu dipilih, dibandingkan dengan alternatif tindakan yang lain. Sedangkan pengertian informasi akuntansi diferensial menurut Munawir (2002), yaitu informasi biaya yang akan terjadi dimasa depan (future cost) yang diperkirakan akan berbeda untuk setiap alternatif dan bermanfaat bagi manajemen untuk pengambilan keputusan memilih salah satu alternatif tindakan yang terbaik.

PT Ciomas Adisatwa adalah perusahaan yang bergerak dalam divisi budidaya dan pengolahan ayam. Perusahaan yang telah mendapatkan tempat di hati konsumennya harus mampu bersaing mempertahankan prestasinya dengan cara menghasilkan produk yang memiliki harga terjangkau, karena harga merupakan salah satu indikator yang sangat menentukan dalam keberhasilan suatu penjualan. Keberhasilan PT Ciomas Adisatwa dapat dilihat dari laba yang terus meningkat dari tahun ketahun, yang dipengaruhi oleh tingkat penjualan yang semakin tinggi. Hal tersebut dapat diartikan bahwa permintaan ayam olahan di masyarakat Indonesia semakin meningkat, sehingga PT Ciomas Adisatwa harus mempertahankan pasar dan lebih meningkatkan jumlah konsumen.

Karena produk yang dihasilkan PT Ciomas Adisatwa sangat beragam, PT Ciomas Adisatwa harus mampu mendapatkan bahan baku utama yang cukup banyak setiap harinya agar mampu memenuhi permintaan pasar. PT Ciomas Adisatwa memiliki beberapa alternatif dalam memperoleh ayam broiler yang merupakan bahan baku utama, salah satunya yaitu melalui program kemitraan bersama masyarakat. Menurut Notoatmodjo (2003), kemitraan adalah suatu kerja sama formal antara individu-individu, kelompok-kelompok atau organisasi-organisasi untuk mencapai suatu tugas atau tujuan tertentu.

Program kemitraan bersama masyarakat adalah perusahaan menjalin kerjasama dengan masyarakat dalam proses pemeliharaan ayam broiler. Dalam hal ini, perusahaan menyediakan berbagai macam kebutuhan yang diperlukan dalam proses pemeliharaan ayam broiler. Mulai dari bibit ayam, pakan ayam dan obatobatan ayam. Masyarakat hanya menyiapkan kandang dan tenaga kerja, kemudian hasil ternak tersebut dijual kembali ke PT Ciomas Adisatwa sebagai bahan baku utama produk ayam olahan. Kemitraan tersebut dimaksudkan perusahaan sebagai sarana memperoleh bahan baku dengan mudah. Selain melalui program kemitraan tersebut, PT Ciomas Adisatwa pun memiliki peternakan yang dikelola sendiri sebagai pemasok kebutuhan bahan bakunya.

Alternatif - alternatif tersebut dilakukan dengan maksud untuk menekan biaya yang dikeluarkan untuk memperoleh 
bahan baku utama, karena penghematan dan efisiensi biaya perolehan bahan baku akan mempengaruhi harga jual suatu produk. Namun menjalin kemitraan yang kasat mata terlihat lebih mudah ternyata ada hal yang harus dipertimbangkan oleh perusahaan, dimana perusahaan tidak mampu menjamin keberlangsungan kemitraan tersebut secara terus menerus. Pada suatu waktu mitra dapat berhenti atas keinginannya sendiri tanpa harus meminta persetujuan dari kerjasama dengan perusahaan.

Hal tersebut yang melatarbelakangi penelitian ini untuk dilakukan, jika saja perusahaan fokus dengan satu alternatif saja dalam memperoleh bahan baku, maka perusahaan akan mendapatkan bahan baku dengan lebih efisien, dan keuntungan-keuntungan yang akan diterima perusahaan akan terasa lebih maksimal. Selain itu, risiko yang mungkin diterima perusahaan jika tidak memilih satu alternatif akan semakin besar. Karena jika suatu waktu para kemitraan mundur dari kerjasama, dan jumlah bahan baku dari peternakan sendiri tetap, maka perusahaan akan mengalami risiko kekurangan pasokan ayam yang akan berdampak pada penjualan. Penelitian ini bertujuan untuk mengevaluasi apakah alternatif yang dipilih perusahaan tersebut telah sesuai dengan harapan PT Ciomas Adisatwa yaitu memperoleh bahan baku dengan lebih efisien. Penelitian ini dilakukan dengan cara membandingkan antara alternatif yang ada yaitu melalui program kemitraan bersama masyarakat atau membuat peternakan sendiri secara keseluruhan agar dapat mengendalikan harga jual suatu produk sehingga mampu mempertahankan peningkatan laba dan lebih mengembangkan usaha. Oleh karena itu, penulis tertarik untuk menulis skripsi yang bertujuan untuk mengetahui berapa besar biaya produksi ayam dengan beternak sendiri dan melalui program kemitraan, serta mengetahui biaya produksi mana yang lebih tepat untuk PT. Ciomans Adisatwa II Unit Klungkung.

\section{METODE}

Penelitian ini merupakan penelitian deskriptif dengan pendekatan kuanntitatif yang bertujuan untuk menggambarkan keadaan atau suatu fenomena yang terjadi di suatu perusahaan. Penelitian ini dilakukan untuk memperoleh informasi mengenai biaya produksi ayam broiler yang dikeluarkan melalui peternakan sendiri dan melalui kemitraan. Penelitian ini diawali dengan merumuskan masalah, mencari kajian teori, pengumpulan data, dan menganalisis data guna menndapatkan hasil penelitian. Hasil yang diperoleh berupa angka-angka merupakan biaya produksi ayam broiler melalui peternakan sendiri dan biaya produksi ayam broiler melalui kemitraan. Hasilnya akan digunakan untuk membandingkan biaya produksi mannakah yang lebih efisien diterapkan dalam perusahaan. Subjek penelitian ini adalah PT Ciomas Adisatwa. PT Ciomas Adisatwa memiliki dua divisi yaitu divisi budidaya ayam broiler dan RPA (Rumah Potong Ayam) atau divisi pemotongan. Objek dari penelitian ini adalah biaya produksi yang digunakan untuk memperoleh bahan baku.Jenis data yang digunakan dalam penelitian ini adalah data kuantitatif, berupa data laporan laba-rugi dan data biaya overhead perusahaan. Sedangkan Sumber data yang digunakan dalam penelitian ini adalah data primer. Data primer diperoleh dari pengamatan langsung dan wawancara dengan divisi budidaya, RPA (divisi pemotongan) serta dengan para mitra perusahaan. Data tersebut akan diambil dan dikumpulkan dengan metode wawancara dan dokumentasi. Metode wawancara dalam penelitian ini dilakukan dengan cara melakukan wawancara langsung dengan pihak perusahaan untuk memperoleh data 
p-ISSN : 2599-1418

e-ISSN : 2599-1426

harga bahan baku, jumlah tenaga kerja, luas \& kapasitas kandang ayam. Kemudian Metode dokumentasi dalam penelitian ini digunakan untuk memperoleh data biaya overhead perusahaan.

Penelitian menggunakan analisis kuantitatif untuk menjawab permasalahan melalui perhitungan tertentu dengan menerapkan teori dan rumus yang berkaitan dengan pokok permasalahan yang menjadi tujuan penelitian. Dengan data yang telah diperoleh peneliti akan menjelaskan data tersebut ke dalam tiga analisis dari setiap alternatif, antara lain analisis alternatif pertama dimana dalam analisis ini perhitungan dilakukan berdasarkan angkaangka yang diperoleh saat perusahaan menggunakan alternatif memperoleh bahan baku utama melalui $100 \%$ peternakan

sendiri. Selajutnya yaitu analisis alternatif kedua dimana dalam analisis ini perhitungan dilakukan berdasarkan angkaangka yang diperoleh saat perusahaan menggunakan alternatif memperoleh bahan baku utama melalui $100 \%$ kemitraan dan yang terakhir yatu analisis alternatif ketiga yang mana dalam analisis ini perhitungan
Jurnal Pendidikan Ekonomi Undiksha

Volume 10 No. 1 Tahun 2018 dilakukan berdasarkan angka-angka yang diperoleh saat perusahaan menggunakan alternatif memperoleh bahan baku utama melalui kombinasi $50 \%$ membuat peternakan sendiri dan 50\% melalui kemitraan. Analisis tersebut di atas digunakan untuk mempermudah peneliti dalam membandingkan efisiensi biaya dari tiap kemungkinan alternatif yang ada dengan menggunakan perhitungan biaya diferensial.

\section{HASIL DAN PEMBAHASAN}

Hasil

Biaya-Biaya untuk Memproduksi Ayam Broiler Melalui Peternakan Sendiri dan Melalui Kemitraan.

Biaya-biaya yang dikeluarkan perusahaan dalam memproduksi ayam broiler melalui peternakan sendiri yaitu biaya bahan baku, biaya tenaga kerja langsung, dan biaya aoverhead pabrik.

Data yang berkaitan dengan biaya bahan baku, akan disajikan dalam tabel 1 tentang biaya bahan baku untuk memproduksi ayam broiler PT. Ciomas Adisatwa.

Tabel 1. Biaya Bahan Baku

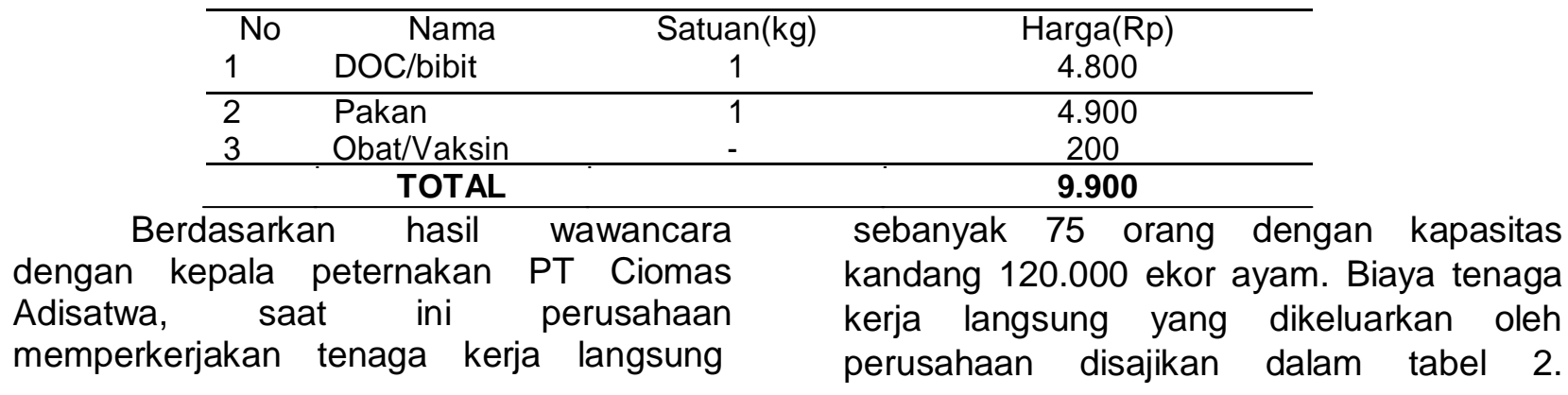

Tabel 2. Biaya Tenaga Kerja Langsung

\begin{tabular}{cccc}
\hline Jenis Pekerjaan & Jumlah Pekerja & Upah/ per orang (Rp) & Upah/Bulan \\
\hline Perawatan Ayam & 75 & 2.400 .000 & 180.000 .000 \\
\hline
\end{tabular}

Biaya overhead merupakan biayabiaya yang harus dikeluarkan divisi budidaya PT Ciomas Adisatwa untuk mengolah bibit ayam broiler menjadi ayam broiler yang siap diperjualbelikan. Biayabiaya ini bisa bersifat langsung dan tak 
p-ISSN : 2599-1418

e-ISSN : 2599-1426
Jurnal Pendidikan Ekonomi Undiksha Volume 10 No. 1 Tahun 2018 langsung, sesuai kaitannya terhadap proses produksi yang dilakukan. Biaya overhead yang dikeluarkan perusahaan antara lain yaitu pertama biaya tenaga kerja tak langsung. Biaya tenaga kerja tak langsung dalam proses produksi ayam broiler antara lain biaya gaji mandor kandang sebesar Rp. 2.400 .000 ada 3 orang mandor, jadi Rp. 2.400.000 x $3=$ Rp. 7.200.000. Kemudian biaya gaji satpam kandang sebesar $R p$. 1.800 .000 ada enam orang satpam, jadi Rp. 1.800 .000 x $6=$ Rp. 10.800 .000 . Total biaya tenaga kerja tak langsung yang dikeluarkan perusahaan selama sebulan adalah $\mathrm{Rp}$. $7.200 .000+$ Rp. $10.800 .000=$ Rp. 18.000.000. Yang kedua yaitu biaya Penyusutan. Biaya penyusutan terdiri dari biaya penyusutan kandang ayam. Berdasarkan hasil wawancara kandang terbesar PT Ciomas Adisatwa di Klungkung adalah berkapasitas 120.000 ekor ayam, yaitu kandang dengan luas $1500 \mathrm{~m}^{2}$ seharga Rp. 4.500.000.000. Dengan umur ekonomis 10 tahun, maka biaya penyusutan kandang yang dikeluarkan oleh perusahaan adalah Rp. 4.500.000.000 : (120 bulan ) = Rp. 37.500.000 per bulan. Selanjunya biaya penyusutan aksesoris kandang. Aksesoris kandang diantaranya adalah wadah untuk makanan dan minuman ayam, yang ditaksir umur ekonomisnya adalah 2 tahun. Dalam satu kandang yang berkapasitas 120.000 ekor diperlukan sebanyak 3000 wadah pakan dan sebanyak 3000 wadah minum ayam, dengan harga Rp. 30.000 untuk setiap wadah. Dengan demikian biaya yang harus dikeluarkan perusahaan untuk biaya penyusutan aksesoris adalah ( Jumlah wadah $\mathrm{x}$ harga wadah : 2 tahun $)=(6.000 \mathrm{x}$ Rp. $30.000: 24$ bulan ) = Rp. 7.500 .000 per bulan. Kemudian ada biaya listrik dan air, biaya listrik dan air yang dikeluarkan perusahaan untuksarana kandang ayam dalam sebulan adalah sebesar $\mathrm{Rp}$. 2.000.000. Yang terakhir ada biaya telepon, biaya telepon yang dikeluarkan perusahaan untuk sarana di sekitar kandang ayam dalam sebulan adalah sebesar Rp. 400.000. Daftar biaya overhead perusahaan dirangkum pada tabel 3 .

Tabel 3. Daftar Biaya Overhead

\begin{tabular}{ll}
\hline \multicolumn{1}{c}{ Jenis Biaya Overhead } & \multicolumn{1}{c}{ Jumlah (Rp) } \\
\hline 1. Biaya tenaga kerja tak langsung & 18.000 .000 \\
2. Biaya penyusutan kandang & 37.500 .000 \\
3. Biaya penyusutan aksesoris kandang & 7.500 .000 \\
4. Biaya listrik dan air & 2.000 .000 \\
5. Biaya telepon & 400.000 \\
& $\mathbf{6 5 . 4 0 0 . 0 0 0}$ \\
\hline
\end{tabular}

\section{TOTAL}

Selanjutnya untuk mencari biaya produksi per kilogram ayam, maka peneliti mengasumsikan bahwa satu ekor ayam yang siap diperjualbelikan beratnya adalah sama rata yaitu seberat satu Kilogram $(1 \mathrm{Kg})$ per ekor. Melalui wawancara dengan kepala peternakan, dengan kandang seluas 1.500 $\mathrm{m}^{2}$ kapasitas ayam broiler di peternakan sendiri adalah sebanyak 120.000 ekor ayam. Dengan demikian biaya produksi $\underline{65.400 .000}$

ayam broiler per Kilogram $(\mathrm{Kg})$ melalui peternakan sendiri dapat dihitung dengan cara biaya bahan baku dikaliikan dengan 120.000 kemudian ditambah dengan biaya tenaga kerja langsung dan biaya overhead. Dan dibagi dengan jumlah ayam yang dihasilkan kandang seluas $1.500 \mathrm{~m}^{2}$. Sehingga dihasilkan biaya produksi ayam $\begin{array}{lll}\text { sebesar } & \text { Rp. } & 11.945 .\end{array}$ 
Biaya-biaya yang dikeluarkan perusahaan dalam memproduksi ayam broiler melalui kemitraan yaitu biaya bahan baku dan biaya overhead pabrik. Data yang berkaitan dengan biaya bahan baku, akan disajikan dalam tabel 4 \& 5 tentang biaya bahan baku untuk memproduksi ayam broiler melalui kemitraan.

Tabel 4. Biaya Bahan Baku

\begin{tabular}{llcc}
\hline No & \multicolumn{1}{c}{ Nama } & Satuan $(\mathrm{kg})$ & Harga(Rp) \\
\hline 1 & DOC/bibit & 1 & 4.800 \\
2 & Pakan & 1 & 4.900 \\
3 & Obat/Vaksin & - & 200 \\
\hline & TOTAL & & 9.900
\end{tabular}

Tabel 5. Biaya Bahan Baku (Kontrak)

\begin{tabular}{llcc}
\hline No & \multicolumn{1}{c}{ Nama } & Satuan(kg) & Harga(Rp) \\
\hline 1 & DOC/bibit & 1 & 5.800 \\
2 & Pakan & 1 & 7.700 \\
3 & Obat/Vaksin & - & 200 \\
\hline & TOTAL & & $\mathbf{1 3 . 7 0 0}$
\end{tabular}

Tabel biaya bahan baku 4 dan tabel biaya bahan baku 5 menunjukan adanya perbedaan harga dari masing-masing bahan baku. Hal ini berdasarkan hasil dari wawancara peneliti terhadap beberapa kemitraan dan terhadap divisi budidaya PT Ciomas Adisatwa bahwa adanya perbedaan harga tersebut. Dimana di dalam sebuah kontrak yang dilakukan pihak perusahaan dengan pihak mitra, perusahaan telah mendapatkan keuntungan dari selisih harga bahan baku yang terdapat di dalam kontrak dan harga pokok bahan baku itu sendiri.

Biaya overhead di dalam kemitraan ini akan dimunculkan oleh peneliti sebagai biaya kontrol, karena pada setiap bulan perusahaan selalu datang untk mengontrol ke kandang kemitraan untuk memastikan kondisi mitra sehingga dapat menghasilkan ayam broiler yang sehat. Jumlah kemitraan yang peneliti dapat dari hasil wawancara adalah 80 kemitraan, dengan kapasitas 5000 ekor ayam. Biaya kontrol yang dikeluarkan perusahaan setiap bulan adalah sebesar Rp. 80.000.000. Jadi untuk mendapatkan biaya kontrol per $\mathrm{Kg}$ ayam adalah dengan cara : Biaya Kontrol =
(Jumlah kemitraan $x$ kapasitas ayam di kemitraan $)=$ Rp. $80.000 .000:(80 \times 5.000=$ 400.000 ekor) $=200$. Jadi biaya kontrol tiap $\mathrm{Kg}$ ayam adalah sebesar Rp. 200 (3) Perhitungan biaya produksi ayam broiler per kilogram $(\mathrm{kg})$ melalui program kemitraan. Dalam penelitian ini penulis menggunakan

harga kontrak yang berlaku pada bulan Juni 2017. Dengan demikian perhitungan biaya produksi 1 Kilogram $(\mathrm{Kg})$ ayam broiler melalui kemitraan adalah :

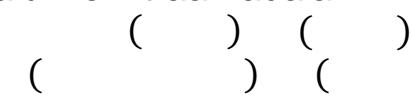

$$
X
$$

Ket:

$X$ : Biaya produksi $1 \mathrm{~kg}$ ayam melalui kemitraan

a : Biaya bahan baku per ekor

b : Total biaya kontrol per ekor

c: Harga kontrak ayam saat panen

d : Harga kontrak bahan baku per ekor

Jadi, biaya produksi $1(\mathrm{Kg})$ ayam melalui kemitraan adalah Rp. 10.885 . 
p-ISSN : 2599-1418

e-ISSN : 2599-1426
Jurnal Pendidikan Ekonomi Undiksha Volume 10 No. 1 Tahun 2018

\section{Biaya Produksi yang Lebih Efisien untuk PT. Ciomas Adiisatwa}

Analisis perhitungan biaya diferensial yang akan dikeluarkan oleh perusahaan dalam pengambilan keputusan memperoleh bahan baku utama melalui $100 \%$ peternakan sendiri, $100 \%$ kemitraan atau kombinasi $50 \%$ peternakan dan $50 \%$ kemitraan.

Dalam melakukan analisis perhitungan biaya diferensial, PT Ciomas Adisatwa dihadapkan pada tiga pilihan alternatif pengambilan keputusan yang berhubungan dengan cara perolehan bahan baku, untuk dapat mengefisiensikan biaya produksi pada divisi pemotongan. Data yang diperoleh oleh peneliti berdasarkan hasil wawancara adalah bahwa setiap bulannya divisi budidaya yang memasok ayam broiler kepada divisi pemotongan ayam adalah sejumlah 288.000 ekor ayam.

Berdasarkan perhitungan data biaya produksi ayam broiler per Kilogram $(\mathrm{Kg})$ pada divisi budidaya di atas, dan data pasokan bahan baku kepada divisi pemotongan setiap bulan, maka efisiensi biaya bahan baku dari beberapa alternatif pengambilan keputusan dapat dihitung dengan tiga alternatif, yaitu untuk alternatif pertama biaya produksi bahan baku utama (ayam broiler) melalui 100\% peternakan sendiri dapat dihitung dengan cara Biaya produksi ayam broiler per Kilogram $(\mathrm{Kg})$ melalui peternakan sendiri $X$ Jumlah ayam yang dibutuhkan setiap bulan pada divisi pemotongan.

Alternatif kedua, biaya produksi bahan baku utama (ayam broiler) melalui 100\% menjalin kemitraan dapat dihitung dengan cara Biaya produksi ayam broiler per Kilogram $(\mathrm{Kg})$ melalui kemitraan $X$ Jumlah ayam yang dibutuhkan setiap bulan pada divisi pemotongan.

Dan yang terakhir alternatif ketiga, biaya produksi bahan baku utama (ayam broiler) melalui kombinasi $50 \%$ peternakan sendiri dan $50 \%$ menjalin kemitraan dapat dihitung dengan cara ( (

Penulis menyajikan hasil perhitungan di atas dalam sebuah tabel sebagai berikut.

Tabel 6. Perbandingan Biaya Diferensial Antara Ketiga Alternatif

\begin{tabular}{|c|c|c|c|}
\hline & Alternatif 1 & Alternatif 2 & Alternatif 3 \\
\hline Keterangan & $\begin{array}{c}\text { Membuat peternakan } \\
100 \%\end{array}$ & $\begin{array}{c}\text { Melalui kemitraan } \\
100 \%\end{array}$ & $\begin{array}{l}\text { Melalui kombinasi } \\
50 \% \text { peternakan, } \\
\text { 50\% kemitraan. }\end{array}$ \\
\hline
\end{tabular}

Biaya Diferensial

$\begin{array}{lll}\text { Per Unit }(\mathrm{Kg}) & \mathrm{Rp} .11 .945 & \mathrm{Rp} .10 .885\end{array}$

Biaya Diferensial

$\begin{array}{llll}\text { Per Bulan } & \text { Rp. } 3.440 .160 .000 & \text { Rp. } 3.134 .880 .000 & \text { Rp. } 3.287 .520 .000\end{array}$

Biaya Diferensial Per Tahun Rp. 41.281 .920 .000

Rp. 37.618 .560 .000

Rp. 39.450 .024 .000

\section{PEMBAHASAN}

Dari hasil perhitungan biaya diferensial dengan menggunakan tiga alternatif dalam pengambilan keputusan yang berhubungan dengan cara perolehan bahan baku, diperoleh beberapa perbandingan dari ketiga alternatif tersebut. Dari perbandingan itu bisa diketahui 
keuntungan yang diperoleh bagi perusahaan maupun bagi mitra. Untuk alternatif yang pertama dengan membuat peternakan 100\%, keuntungan yang diperoleh perusahaan yaitu, pertama dapat memiliki aset berupa lahan dan kandang, kedua mendapat pasokan bahan baku utama dengan pasti, sedangkan tidak akan ada keuntungan bagi mitra. Untuk alternatif yang ke-dua melalui kemitraan $100 \%$, keuntungan yang diperoleh perusahaan yaitu pertama, perusahaan dapat mengoperasionalkan kapasitas pabriknya secara maksimal tanpa perlu memiliki lahan. Kedua, perusahaan dapat menghemat biaya tenaga kerja langsung. Ketiga, terjaminnya pasokan bahan baku utama RPA (divisi pemotongan). Keempat, perusahaan dapat berperan dalam upaya peningkatan pendapatan, kesejahteraan, sehingga dapat menciptakan pemerataan ekonomi di masyarakat. Dan yang kelima, tidak adanya resiko kerusakan kandang dan lainnya. Sedangkan keutungan bagi mitra yaitu pertama, mendapatkan bantuan modal. Kedua, mendapatkan tambahan pengetahuan beternak yang lebih baik. Ketiga, berkurangnya resiko gagal produksi. Keempat, tidak adanya resiko hasil panen tidak laku dipasaran. Dan kelima, mendapatkan penghasilan. Untuk alternatif yang ke-tiga melalui kombinasi 50\% peternakan sendiri dan $50 \%$ kemitraan, keuntungan yang diperoleh perusahaan yaitu pertama, perusahaan dapat mengoperasionalkan kapasitas pabriknya secara sebagian tanpa perlu memiliki lahan. Kedua, perusahaan dapat menghemat sebagian biaya tenaga kerja langsung. Ketiga, terjaminnya pasokan bahan baku utama RPA (divisi pemotongan). Dan keempat, dapat berperan dalam upaya peningkatan pendapatan, kesejahteraan, sehingga dapat menciptakan pemerataan ekonomi di masyarakat. Sedangkan keuntungan yang bisa diperoleh bagi mitra yaitu pertama, mitramendapatkan bantuan modal. Kedua, mitra mendapatkan tambahan pengetahuan beternak yang lebih baik. Ketiga, berkurangnya resiko gagal pproduksi. Dan keempat tidak adanya risiko hasil panen tidak laku dipasaran.

Berdasarkan perbandingan tersebut, dapat disimpulkan bahwa yang diperoleh kedua belah pihak jika melalui alternatif kedua yaitu melalui kemitraan $100 \%$ adalah lebih mendapatkan keuntungan jika dibandingkan dengan alternatif lain. Selain keuntungan, program kemitraan yang lebih banyak di pedesaan tidak mengganggu masyarakat sekitar karena berdasarkan wawancara dengan kepala desa setempat, sejauh ini tidak ada keluhan dari masyarakat, karena umumnya rumah warga yang memiliki kandang ayam adalah rumah warga yang memiliki halaman yang luas, dan juga jarak setiap rumah di daerah tersebut masih cukup berjauhan.

\section{SIMPULAN DAN SARAN Simpulan}

Berdasarkan hasil penelitian dan pembahasan, maka dapat disimpulkan. Pertama, besar biaya produksi yang harus dikeluarkan PT Ciomas Adisatwa Klungkung dengan beternak sendiri yaitu Rp. 3.440.160.000, sedangkan besar biaya produksi yang harus dikeluarkan $\mathrm{PT}$. Ciomas Adisatwa Klungkung denga menjalin kemitraan yaitu Rp. 3.134.880.000. Dan kedua, menjalin kemitraan $100 \%$ adalah alternatif yang paling tepat untuk PT Ciomas Adisatwa. Dalam perhitungan efisiensi biaya produksi secara kuantitatif menjalin kemitraan 100\% adalah alternatif yang paling tepat untuk mendapatkan biaya produksi yang lebih efisien dibandingkan alternatif lain. Berdasarkan analisis, peneliti melihat lebih banyak manfaat yang dirasakan perusahaan jika menjalin kemitraan $100 \%$, tidak hanya perusahaan yang merasakan manfaat dari menjalin kemitraan tersebut, masyarakat yang menjalin kemitraan pun merasakan manfaatnya yaitu mendapatkan penghasilan, serta menambah lapangan pekerjaan baru untuk masyarakat sekitar. 
p-ISSN : 2599-1418

e-ISSN : 2599-1426
Jurnal Pendidikan Ekonomi Undiksha Volume 10 No. 1 Tahun 2018

\section{Saran}

Berdasarkan simpulan di atas, maka dapat dikemukakan beberapa saran. Pertama, perusahaan disarankan untuk mampu mempertahankan jumlah kemitraan saat ini, dan harus meningkatkan jumlah kemitraan secara bertahap dan terus menerus hingga $100 \%$. Kedua, perusahaan disarankan untuk mampu melayani kemitraan dengan lebih adil, dengan komitmen dalam melaksanakan perjanjian yang ada dengan prinsip saling menguntungkan bagi kedua belah pihak. Ke-tiga, perusahaan disarankan untuk mempertahankan kepercayaan mitra terhadap perusahaan, misalnya dengan cara mengadakan pertemuan berkala untuk membahas keluhan-keluhan mitra dan sekaligus untuk melakukan sosialisasi tentang penetapan harga kontrak. Karena penyebaran informasi penurunan harga pasar sangat cepat diperoleh mitra, namun harga kontrak dengan perusahaan berlaku tetap bahkan lama tidak diubah sebagaimana yang dikeluhkan oleh mitra. Dan ke-empat, perusahaan disarankan untuk lebih mensosialisasikan program kemitraan dan keuntungan yang didapat harus lebih adil dan menarik, karena akan mampu menarik para sarjana-sarjana muda yang telah mempelajari peternakan. Sehingga perusahaan tidak hanya dapat menguntungkan pihak internal saja, namun dapat membantu pemerintah untuk menciptakan lapangan pekerjaan baru, dan turut serta dalam upaya pemerintah untuk menciptakan ketahanan nasional.

\section{DAFTAR PUSTAKA}

Abdul Halim \& Bambang, Supomo. 2005. Akuntansi Manajemen. Yogyakarta: BPFE.

Bustami dkk. 2009. Akuntansi Biaya. Jakarta: Mitra Wacana Media

Hansen \& Mowen. 2004. Manajemen Biaya, Edisi Bahasa Indonesia. Buku Kedua. Jakarta: Salemba Empat
Krismiaji. (2010). Sistem Informasi Akuntansi edisi ketiga. Yogyakarta: Unit Penerbit dan Percetakan Sekolah Tinggi IImu YKPN

Mulyadi. 2001. Akuntansi Manajemen. Konsep, Manfaat dan Rekayasa. Jakarta: Salemba Empat.

Munawir, S. 2002. Akuntansi Keuangan dan Manajemen. Yogyakarta: BPFF, Yogyakarta.

Notoatmodjo, soekidjo. 2003. Pengembangan sumber daya manusia. Jakarta: rineka cipta

Prawironegoro, Darsono Dan Ari Purwanti. 2009. Akuntansi Manajemen, Edisi Ketiga. Jakarta : Mitra Wacana Media

Sunarto. 2004. Akuntansi Manajemen. Yogyakarta: BTFE-UST.

Supomo, Bambang. 2012. Akuntansi Manajemen Suatu Sudut Pandang. Yogyakarta : BPFE. 